\title{
DAMPAK INTEGRASI EKONOMI ASEAN TERHADAP PERDAGANGAN INDONESIA PADA SEKTOR KENDARAAN RODA EMPAT
}

\author{
K. Dianta A. Sebayang*
}

\begin{abstract}
This study aims to determine the significane of economic integration to Indonesia trade between ASEAN countries, especially the vehicle sector since ASEAN FREE TRADE AREA (AFTA) between 1991-2006. The methodology used is the Gravity model which often used to analyze bilateral trade, the effects of liberalization and trade agreements. The population in this study are the most dominant Indonesia trading partners at the four-wheeled vehicle, which are Malaysia, Philippines, Thailand, and Singapore, as the ASEAN members, and as comparison Australia, South Korea, Japan and the United States as non ASEAN members. The results showed that based on the estimation results, AFTA has a significant impact to Indonesia four-wheeled vehicle trade. The results of this study is expected to be uses as a reference for policy makers of ASEAN members and the private sector, especially Multi National Company (MNC) to formulated policy which are more efficient and effective on the automotive sector among ASEAN members.
\end{abstract}

Keywords: economic integration, the Gravity model, AFTA

\section{PENDAHULUAN}

Pada pertemuan puncak ke 4 negara-negara yang tergabung dalam Asean tahun 1992, anggota ASEAN mencetuskan keinginan untuk segera melaksanakan AFTA yang semula dijadwalkan pada tahun 2008 dipercepat menjadi tahun 2003. Integrasi perekonomian nasional dengan perekonomian regional/global seperti AFTA, APEC, WTO/GATTmemang tidak bisa dihindari. Suka tidak suka, mau tidak mau, kenyataan integrasi perekonomian dunia ini memang harus dihadapi. Pada waktu perjanjian AFTA disetujui, ASEAN

\footnotetext{
* K. Dianta A. Sebayang. Dosen Fakultas Ekonomi Universitas Negeri Jakarta
}

memiliki 6 anggota Brunei, Indonesia, Malaysia, Filipina, Singapura dan Thailand. Vietnam menjadi anggota pada tahun 1995, Laos dan Myanmar pada 1997 dan Kamboja 1999. Keempat anggota baru tersebut memiliki peluang lebih longgar (dalam hal waktu) untuk melaksanakan AFTA, khususnya tariff reduction obligations.

Serangkaian kebijakan telah mengubah lingkungan bisnis buat industri otomotif di ASEAN. Kesepakatan Asian Industrial Cooperative (AICO) yang diimplentasikan pada tahun 1996, dimana terjadi pengurangan tariff dan memberikan tawaran kepada perusahaan yang ikut berpartisipasi mampu merasakan manfaatnya dari 
Common Effective Preferential Tariff (CEPT) yang menetapkan tariff dari 0\%-5\%.

Pada tahun 1998,

Kesepakatan ASEAN Free Trade Area (AFTA) telah diperkenalkan, sebagi hasil dimana dengan CEPT mampu mengverifikasi lebih dari $96 \%$ barang dari seluruh sektor manufakur dan agricultural pada tahun 2002, seperti Indonesia menurunkan tariff lebih rendah pada CBU (Completly Bulit-Up) dan CKD (Completly Knocked-Down) yang diproduksi di ASEAN pada tingkatan 5\% di Januari 2002, diikuti oleh Thailand dan Filipina yang telah mengurangi tingkat tarifnya pada Januari 2004.

\section{TUJUAN PENELITIAN}

Penelitian ini bertujuan untuk menganalisa signifikansi Integrasi Ekonomi terutama dengan pemberlakukan ASEAN FREE TRADE AREA (AFTA) terhadap perdagangan Indonesia pada sektor kendaraan roda empat dan sparepart kendaraan dengan negara ASEAN.

\section{KAJIAN TEORI}

\section{Integrasi Ekonomi}

Kerjasama eknomi, di bidang perdagangan internasional, saat ini mengarah kepada pembentukan kerjasama guna mewujudkan integrasi ekonomi dan keuangan secara regional. Teori integrasi ekonomi mengacu kepada suatu kebijakan komersial atau kebijakan yang secara diskriminatif menurunkan atau menghapuskan hambatan-hambatan perdagangan hanya diantara negaranegara yang saling sepakat untuk membentuk suatu integrasi ekonomi terbatas.

Jenis-jenis Integrasi Ekonomi

1. Pengaturan Perdagangan

Preferensial (Preferential Trade Arrangerents)

2. Kawasan Perdagangan Bebas (Free Trade Area)

3. Persekutuan Pabean (Customs Union)

4. Pasaran Bersama (Common Market)

5. Uni Ekonomi (Economic Union)

\section{Teori Model Gravitasi}

Dalam penelitian ini model yang akan digunakan adalah adaptasi dari Gravity Model yang pertama kali dikenalkan oleh Sir Isaac Newton. Model tersebut diadaptasi sesuai dengan kebutuhan penelitian serta disesuaikan dengan keadaan Indonesia.

Teori gravitasi adalah teori yang menggambarkan tingkat interaksi spasial antar dua entitas atau lebih yang mempunyai gejala fisik (Nijkamp and Reggiani 1992; Harvey, 1969). Berdasarkan teori tersebut dibuatlah suatu persamaan yang disebut dengan Persamaan Gravitasi atau Model Gravitasi (Gravity Mode). Model Gravitasi adalah persamaan/model yang digunakan untuk menganalisa arus antar dua entitas yang terpisah secara geografis.

\section{Model Gravitasi untuk Ekonomi}

Pada tahun 1962, Jan Tinbergen memperkenalkan Model Gravitasi baru. Model tersebut dapat digunakan untuk menghitung arus perdagangan internasional. Persamaan tesebut dirumuskan sebagi berikut: 
$F i j=G \frac{M_{i}^{\alpha} M_{j}^{\beta}}{D_{i j}^{\theta}}$

1. Fij adalah arus dari tempat asal i ke tempat tujuan j. Dapat dikatakan juga bahwa Fij adalah volume total interaksi antara i dan j.

2. Mi dan $\mathrm{Mj}$ adalah variabel yang dapat menggambarkan besarnya suatu negara, berdasarkan faktor ekonominya. Jika ingin mengukur arus dengan satuan uang (seperti nilai ekspor/impor) maka variabel yang biasa digunakan adalah GDP atau GNI (Gross National Income). Jika ingin mengukur arus pergerakan tenaga kerja, maka variabel yang biasa digunakan adalah populasi.

3. Dij adalah jarak antar kedua tempat

4. G adalah konstanta. Nilainya tergantung dari unit apa yang akan digunakan dalam perhitungan.

Selain Tinbergen, telah banyak studi lain yang menggunakan Model gravitasi. Model tersebut telah dikembangkan antara lain oleh Linnemann pada tahun 1966; Bergstrand pada tahun 1985, 1989 dan 1990; Deadorff pada tahun 1995 dan 1998; Evenett dan Keller pada tahun 1998; Mathur pada tahun 1999.

\section{SEJARAH ASEAN}

Asean didirikan berdasarkan deklarasi Bangkok pada tanggal 8 Agustus 1967 oleh lima negara yaitu Indonesia, Malaysia, Philipina, Singapure dan Thailand. Tujuan utama pembentukan ASEAN adalah untuk meningkatkan pertumbuhan ekonomi kawasan. Keanggotaan ASEAN terus bertambah sehingga pada saat ini sudah berjumlah 10 negara. Diawali dengan keiikutsertaan Brunei pada tanggal 8 Januari 1984, kemudian Vietnam pada tanggal 28 Juli 1995, diikuti Laos dan Myanmar pada tanggal 23 Juli 1997, dan terakhir Kamboja pada tanggal 30 April 1999.

\section{ASEAN Preferential Trade Agreement (PTA)}

Mengingat salah satu tujuan pembentukan ASEAN adalah percepatan pertumbuhan ekonomi dan mengingat pula volume perdagangan intra-ASEAN yang masih sangat rendah terutama ketika ASEAN pertama kali terbentuk pada tahun 1967, maka pada taggal 25 Februari 1977 dibentuk kerja sama perdagangan preferensi (Preferential Trade Arrangement/PTA) antar negara ASEAN atau disebut sebagai ASEAN PTA untuk mengembangkan perdagangan di antar negara ASEAN. ASEAN PTA merupakan komitmen pertama negara ASEAN dalam rangka meningkatkan perdagangan intra kawasan anatara lain melalui pertukaran tarif preferensi khususnya untuk produk makanan, energi dan produk-produk yang termasuk dalam proyek-proyek industri ASEAN dan peningkatan penggunaan bahan baku yang tersedia di kawasan.

Peningkatkan perdagangan tersebut dilakukan melalui skema sebagai berikut:

1. pengurangan tarif melalui pemberian tarif preferensi

2. mendukung kredit ekspor menggunakan suku bungan preferensi 
3. kontrak kuantitas jangka panjang

4. preferntial procurement dari instansi pemerintah dan

5. pembebasan hambatan non-tarif

\section{ASEAN Free Trade Area}

Momen

penting

pengembangan kerjasama di bidang ekonomi dicapai pada 1992 ketika ASEAN menyepakati Kerangka Persetujuan mengenai Peningkatan Kerjasama Ekonomi ASEAN (Framework Agreement on Enhancing ASEAN Economic Cooperation) yang berfungsi sebagai payung bagi semua bentuk kerjasama ekonomi ASEAN di masa mendatang. Pada tahun yang sama, ASEAN juga menyepakati pembentukan Kawasan Perdagangan Bebas ASEAN (AFTA).

Pembentukan AFTA ditujukan untuk meningkatkan daya tarik ASEAN sebagai basis produksi melalui pengembangan pasar regional. AFTA diwujudkan dengan cara menghilangkan hambatan-hambatan perdagangan, berupa tarif maupun non tarif dalam waktu 15 tahun kedepan terhitung tanggal 1 Januari 1993 dengan menggunakan skema Common Effective Preferential Tariff (CEPT) sebagai mekanisme utamanya..

Untuk memperbaiki dan memperkuat aturan-aturan pelaksanaan skema CEPT menjadi lebih menarik bagi para pebisnis dan investor potensial di kawasan, CEPT Rules of Origin serta Operational Certification Procedures telah direvisi dan mulai dilaksanakan pada 1 Januari
2004. Hal-hal yang disempurnakan adalah:

a. metode standar penghitungan local/ASEAN content;

b. prinsip-prinsip penentuan biaya dari ASEAN serta pedoman untuk metodologi penghitungan biaya;

c. perlakuan terhadap barang-barang atau material lokal (locallyprocured); serta

d. perbaikan terhadap proses verifikasi, termasuk verifikasi langsung (on-site verification).

Sidang AEM ke-38 bulan

Agustus 2006 telah menyepakati untuk memberlakukan penghapusan hambatan non-tarif (non tariff barriers), mulai tanggal 1 Januari 2008 bagi ASEAN-5 (Brunei Darussalam, Indonesia, Malaysia, Singapura dan Thailand), dan mulai tanggal 1 Januari 2010 bagi Filipina, serta tanggal 1 Januari 2013 bagi CLMV (Kamboja, Laos, Myanmar dan Vietnam). Di bidang fasilitasi perdagangan, pada tahun 2006 ASEAN menyepakati beberapa kebijakan, yaitu: harmonisasi "tariff nomenclature" dengan penyeragaman sistem klasifikasi tarif; penyederhanaan dan penyelarasan prosedur pemeriksaan kepabeanan melalui ASEAN e-custom, ASEAN Single Window, , serta persetujuan ASEAN Customs Declaration Documents, dan perkembangan terakhir pelaksanaan AFTA ditandai dengan konversi dari ASEAN Harmonized Tariff Nomenclature (AHTN) 2002 ke AHTN tahun 2007, yang untuk sementara prosesnya telah diselesaikan oleh Indonesia dan Thailand. 
K. Dianta A. Sebayang: Dampak Integrasi Ekonomi ASEAN Terhadap Perdagangan Indonesia Pada Sektor Kendaraan Roda Empat

Tabel 3.1

Jumlah Pos Tarif dalam Paket CEPT 2003

\begin{tabular}{|c|c|c|c|c|c|c|c|c|c|c|}
\hline \multirow[t]{2}{*}{ Country } & \multicolumn{5}{|c|}{ Jumlah Pos Tarif } & \multicolumn{5}{|c|}{ Percentage } \\
\hline & IL & TEL & GE & SL & Total & IL & TEL & GE & SL & Total \\
\hline Brunei D & 6.337 & - & 155 & - & 6.492 & 97,61 & - & 2,39 & - & 100,00 \\
\hline Indonesia & 7.217 & - & 68 & - & 7.285 & 99,07 & - & 0,93 & - & 100,00 \\
\hline Malaysia & 10.124 & 218 & 53 & - & 10.395 & 97,39 & 2,10 & 0,51 & - & 100,00 \\
\hline Philipina & 5.642 & - & 16 & - & 5.658 & 99,72 & - & 0,28 & - & 100,00 \\
\hline Singapura & 5.859 & - & - & - & 5.859 & 100,00 & - & - & - & 100,00 \\
\hline Thailand & 9.211 & - & - & - & 9.211 & 100,00 & - & - & - & 100,00 \\
\hline $\begin{array}{l}\text { Total } \\
\text { ASEAN-6 }\end{array}$ & 44.390 & 218 & 292 & - & 44.900 & 98,86 & 0,49 & 0,65 & - & 100,00 \\
\hline Cambodia & 3.115 & 3.523 & 134 & 50 & 6.822 & 45,66 & 51,64 & 1,96 & 0,73 & 100,00 \\
\hline Lao PDR & 2.533 & 856 & 74 & 88 & 3.551 & 71,33 & 36,36 & 2,08 & 2,48 & 100,00 \\
\hline Myanmar & 4.182 & 1.224 & 48 & 18 & 5.472 & 76,43 & 33,32 & 0,88 & 0,33 & 100,00 \\
\hline Vietnam & 6.296 & - & 139 & 51 & 6.486 & 97,07 & 11,36 & 2,14 & 0,79 & 100,00 \\
\hline $\begin{array}{l}\text { Total } \\
\text { ASEAN-4 }\end{array}$ & 16.126 & 5.603 & 395 & 207 & 22.331 & 72,21 & 33,02 & 1,77 & 0,93 & 100,00 \\
\hline $\begin{array}{l}\text { Total } \\
\text { ASEAN-10 }\end{array}$ & 60.516 & 5.821 & 687 & 207 & 67.231 & 90,01 & 8,66 & 1,02 & 0,31 & 100,00 \\
\hline
\end{tabular}

Sumber : Sidang ke-16 AFTA Council, 11 September 2002, Brunei Darussalam.

Catatan: IL = Inclusion List

TEL $\quad=$ Temporary Exclusion List

$\mathrm{GE} \quad=$ General Exception

$\mathrm{SL}=$ Sensitive List

\section{ASEAN Industrial Cooperation Scheme (AICO)}

SKEMA kerjasama industri antaranegara-negara anggota ASEAN melalui ASEAN Industrial Cooperation Scheme (Skema AICO) merupakan bentuk kerjasama sektor industri yang paling akhir, dan masih diberlakukan hingga kini. Skema ini merupakan suatu terobosan di bidang industri di negara-negara anggota ASEAN yang bermanfaat dalam meningkatkan daya saing, dan mendorong terciptanya kerjasama "resource sharing" di antara industri manufaktur di kawasan ini.

Kerjasama industri melalui skema ASEAN Industrial Cooperation Scheme (AICO) dengan pemberian preferensi bea masuk 0 - $5 \%$ bagi industri-industri di ASEAN yang melakukan kerjasama industri telah dimulai sejak ditandatanganinya Basic Agreement on the ASEAN Industrial Cooperation Scheme pada bulan April 1996 dan Agreement ini mulai diberlakukan mulai 1 Nopember 1996. 
Tabel 3.2

Tingkat Preferensi Tarif dalam Pengaturan AICO sejak 2003

\begin{tabular}{|r|l|c|c|}
\hline a. & Brunei Datussalam & - & $0 \%$ \\
\hline b. & Kerajaan Kamboja & - & $0 \%$ \\
\hline c. & Republik Indonesia & - & $0 \%$ \\
\hline d. & Republik Demokratik Rakyat Laos & - & $0 \%$ \\
\hline e. & Malaysia & - & $0 \%$ \\
\hline f. & Uni Myanmar & - & $0-5 \%$ \\
\hline g. & Republik Filipina & - & $0-1 \%$ \\
\hline h. & Republik Siagapura & - & $0 \%$ \\
\hline i. & Kerajaan Thailand & - & $0-3 \%$ \\
\hline j. & Republik Sosialis Vietnam & - & $0-5 \%$ \\
\hline
\end{tabular}

Sumber: Peraturan Presiden Republik Indonesia Nomor 16 Tahun 2006

Dalam ketentuan skema AICO yang baru diatur bahwa perusahaan industri yang menggunakan skema ini, akan mendapatkan preferensi bea masuk hingga $0 \%$. Pada garis besarnya terdapat tiga tujuan utama dari penerapan skema AICO.

Dilihat dari jenis industri yang disetujui aplikasinya, maka industri otomotif menempati urutan pertama, yaitu $88,07 \%$ dari total aplikasi yang disetujui. Banyaknya industri otomotif yang mendominasi kerjasama AICO ini disebabkan oleh beberapa hal, antara lain banyaknya komponen di bidang industri otomotif yang memungkinkan untuk dipertukarkan antara produsen di negara yang berbeda, sehingga jenis ini mempunyai tingkat komplementer yang tinggi.

Alasan lain adalah industri otomotif kebanyakan merupakan industri multinasional, dimana walau industri tersebut berlokasi di negara yang berbeda tetapi mempunyai prinsipal yang sama, sehingga kerjasama AICO dapat lebih mudah diatur.

\section{Gambaran Umum Sektor Otomotif ASEAN}

Sektor Otomotif mendapatkan perhatian dari Negara-negara ASEAN melalui skema kesepakatankesepakatan pada industri otomotif dimulai dengan skema ASEAN Industrial Co-operation (AIC) pada tahun 1981, dilanjutkan dengan skema Brand-to-Brand Complementation (BBC) pada tahun 1988 dan skema AICO (ASEAN Industrial Co-operation Organization) pada tahun 1996. 
K. Dianta A. Sebayang: Dampak Integrasi Ekonomi ASEAN Terhadap Perdagangan Indonesia Pada Sektor Kendaraan Roda Empat

Tabel 3.2

Jumlah Arrangement AICO Pada Sektor Otomotif

\begin{tabular}{|l|c|l|l|}
\hline \multicolumn{1}{|c|}{ COMPANY } & $\begin{array}{c}\text { NO. OF } \\
\text { ARRANGEMENT }\end{array}$ & PRODUCT CATEGORY & \multicolumn{1}{c|}{ PARTICIPATING COUNTRIES } \\
\hline Sanden & 1 & Automotive components & Singapore, Thailand \\
\hline Denso & 8 & Automotive components & Indonesia, Malaysia, Philippines, Thailand \\
\hline Toyota & 33 & Automotive CKD pack & Indonesia, Malaysia, Philippines, Thailand \\
\hline Honda & 44 & Automotive CKD pack & Indonesia, Malaysia, Philippines, Thailand \\
\hline Volvo & 7 & Automotive CKD pack & Malaysia, Thailand \\
\hline Sony & 2 & Electronics & Singapore, Thailand, Vietnam \\
\hline Thai Steel Cable/Armstrong & 1 & Automotive components & Malaysia, Thailand \\
\hline Clipsal/Bowden & 1 & Electrical & Indonesia, Malaysia \\
\hline Isuzu & 2 & Automotive CKD pack & Indonesia, Philippines, Thailand \\
\hline Yanmar & 1 & Agriculture machinery & Indonesia, Thailand \\
\hline Matsushita & 2 & Electronics & Indonesia, Malaysia, Thailand, Philippines \\
\hline Nissan & 6 & Automotive CKD pack & Indonesia, Malaysia, Thailand, Philippines \\
\hline Nestle/Goya & 5 & Food processing & Indonesia, Malaysia, Thailand, Philippines \\
\hline Ford & 2 & Automotive CKD pack \& CBU & Philippines, Thailand \\
\hline Mistubishi Electric/Lippo Melco & 3 & Automotive components & Indonesia, Philippines, Thailand \\
\hline Showa & 1 & Automotive components & Indonesia, Thailand \\
\hline Mitsubishi & 2 & Automotive CKD pack & Indonesia, Philippines, Thailand \\
\hline Asahi Glass & 1 & Safety glass & Philippines, Thailand \\
\hline Daihatsu & 1 & Automotive CKD pack & Indonesia, Malaysia \\
\hline Mistuba & 1 & Automotive components & Philippines, Thailand \\
\hline Yamaha & 1 & Automotive CKD pack & Indonesia, Malaysia \\
\hline Samsung & 2 & Automotronics & Malaysia, Vietnam \\
\hline Autrans/Harada & 1 & Automotive components & Thailand, Vietnam \\
\hline Hino & 1 & Indonesia, Malaysia, Thailand \\
\hline
\end{tabular}

Sumber: AICO Monitor, Sekretariat ASEAN

\section{METODOLOGI PENELITIAN}

Gravity model adalah salah satu model kerangka empiris yang sering dipergunakan untuk menganalisa perdagangan bilateral, efek liberalisasi dan perjanjianperjanjian perdagangan. Gravity model secara umum tidak mengestimasi efek kemakmuran.

Berdasarkan penelitian sebelumnya mengenai penggunaan gravity model untuk menganalisa perdagangan, penelitian ini akan melakukan beberapa perubahan antara lain nilai ekspor, waktu observasi, jumlah observasi, jumlah jenis pengkodean klasifikasi produk. Dengan demikan formulasi model yang akan dibangun dalam penelitian adalah sebagai berikut:

$$
\begin{aligned}
\log (T T i j)= & a 0+a 1 \log G D P i+a 2 \\
& \log G D P j+a 3 \log d i s t \\
& i j+a 4 \text { DAFTA }+a 5 \\
& D A S E A N+\text { error }
\end{aligned}
$$

Dimana:

$\begin{aligned} T \mathrm{~T} \mathrm{ij}= & \text { Perdagangan Total antara dua } \\ & \text { Negara dalam current US dollar } \\ \mathrm{GDP} \mathrm{i}= & \text { GDP dari Negara } \mathrm{i} \text { dalam current }\end{aligned}$ US dollar 


$\begin{aligned} \text { GDP } \mathrm{j}= & \text { GDP dari Negara } \mathrm{j} \text { dalam current } \\ \text { dist ij }= & \text { US dollar } \\ \text { DAfta dalam kilometer antara } & \text { ibukota Negara i dan } \mathrm{j} \\ = & \text { variabel dummy buat menjelaskan } \\ & \text { apakah AFTA telah diberlakukan. } \\ & \text { Jika AFTA sudah diberlakukan akan } \\ & \text { nilai } 1 . \text { Jika AFTA tidak } \\ & \text { diberlakukan akan diberikan nilai 0 } \\ = & \text { variabel dummy buat menjelaskan } \\ & \text { apakah mitra dagang merupakan } \\ & \text { anggota ASEAN. Jika mitra dagang } \\ & \text { anggota ASEAN akan diberikan } \\ & \text { nilai } 1 . \text { Jika mitra dagang bukan } \\ & \text { anggota ASEAN akan diberikan } \\ & \text { nilai } 0\end{aligned}$

Variabel dependent $T$ Tij adalah perdagangan total dari negara pasangan dalam sektor kendaraan roda empat dan sparepart. Data perdagangan yang digunakan adalah nilai export dalam current US dollars, karena untuk menghindari efek biaya transportasi. TTij adalah keseluruhan export dari negara i ke Negara $j$ atau sebaliknya. Yang berarti variabel ini tidak mengindikasikan arah perdagangan dari satu negara ke negara lain, tetapi perdagangan total dari negara-negara.

Variabel GDP dari negara i digunakan sebagai proxy buat potensi penawaran ekspor dan juga pendapatan dan juga kekuatan ekonominya. Di sisi lain, GDP dari negara $j$ digunakan sebagai proxy untuk menggambarkan kekuatan dari partner country. Dengan demikian diperkirakan koefisien $a 1$ dan $a 2$ akan bertanda positif.

Variabel jarak digunakan sebagai proxy buat biaya transportasi. Jarak jauh antar negara akan meningkatkan biaya. Dengan kata lain, biaya transportasi antara negara yang secara geografis dekat diharapkan lebih rendah daripada antara negara yang relatif jauh. Pada analisa ini diperkirakan koefisien jarak akan bertanda negatif.

Variabel dummy afta digunakan sebagai proxy buat melihat diberlakukannya kesepakatan AFTA, dimana dengan diberlakukan AFTA, akan memberikan dampak yang signifikan bagi perdagangan Indonesia. Pada analisa ini diperkirakan koefisien AFTA akan bertanda positif.

Variabel dummy asean digunakan sebagai proxy buat melihat keanggotaan mitra dagang Indonesia, apakah mitra dagang Indonesia merupakan anggota ASEAN atau bukan. Di sisi lain untuk melihat signifikansi perdagangan Indonesia dengan anggota ASEAN. Pada analisa ini diperkirakan koefisien asean akan bertanda positif.

Populasi dalam penelitian ini adalah mitra dagang Indonesia yang mempunyai nilai perdagangan paling dominan pada produk kendaraan roda empat dan sparepart dengan Indonesia. Mitra dagang Indonesia terdiri dari negara anggota ASEAN dan non ASEAN. Mitra dagang anggota ASEAN akan dijadikan sebagai acuan untuk melihat signifikansi perdagangan Indonesia dengan sesama anggota ASEAN yang akan terdiri dari Malaysia, Phillipines, Thailand dan Singapure. Sedangkan mitra dagang non ASEAN akan dijadikan sebagai pembanding perdagangan Indonesia, apakah perdagangan Indonesia dengan negara anggota ASEAN signifikan atau tidak, mitra dagang non ASEAN akan dibatasi hanya pada Australia, Japan, Korea Selatan, dan Amerika . 
Periode waktu yang akan dilihat adalah selama 15 tahun dari tahun 1991 sampai tahun 2006, dimana kesepaktan AFTA baru berlaku mulai tahun 2003.

Penelitian akan menggunakan data pada periode tahun 1991 sampai tahun 2006 dengan klasifikasi pengkodean berupa Standard International Trade Classification (SITC) yang dikembangkan oleh Perserikatan Bangsa-Bangsa, Klasifikasi pengkodean buat kendaraan roda empat adalah SITC 781.

Sumber data yang digunakan adalah dari dokumen publik dan catatan resmi termasuk arsip-arsip maupun dari website, serta media massa. Adapun jenis data sekunder Time Series dan Cross Section yang digabung menjadi Data Panel. Data yang dibutuhkan dalam penelitian ini adalah nilai perdagagan sektor kendaraan roda empat dan sparepart akan diambil dari Wits-Comtrade dan Departemen Perdagangan Republik Indonesia, data GDP akan diambil dari International Monetary Fund melalui www.imf.org , sedangkan jarak akan diambil dari www.indo.com/distance.

\section{PENGOLAHAN MODEL}

Beberapa variabel dalam kedua model dalam penelitian, diubah menjadi logaritma natural (In). Hal ini dilakukan untuk menjembatani beragamnya satuan dalam model. Variabel yang diubah adalah variabel total, GDPi, GDPj, dan jarak. Sedangkan untuk dummy AFTA dan dummy ASEAN tidak perlu diubah ke dalam bentuk Ln, karena satuannya yang memang sudah dalam bentuk persentase. Penambahan Ln pada model menjadikan hasil dalam bentuk persentase, dan output diintepretasikan sebagai nilai pertumbuhan atau elastisitas. Pengolahan model dalam penelitian ini menggunakan pendekatan efek acak (random effect), bukannya kuadrat terkecil (pooled least square) dan bukannya pendekatan efek tetap (fixed effect).

Setelah melakukan Hausman Test dengan software Stata/SE.9, maka hasil regresi terbaik kedua model adalah dengan pendekatan efek acak (random effect). Pendekatan efek tetap (fixed effect) tidak dapat dipilih, karena jika menggunakan pendekatan ini maka secara otomatis variabel jarak akan didrop (tidak diikutsertakan dalam persamaan regresi). Hal ini dilakukan baik pada model SITC 781 dan SITC 784. Variabel jarak didrop karena variansi dari jarak antar negara sangat kecil, dan bahkan tidak ada variansi antar waktu (jarak suatu negara dengan negara satunya sama di setiap tahun), sehingga menghasilkan singular matrix. Hal ini melanggar asumsi ekonometri, oleh karena itu agar matriks tidak singular maka variabel jarak harus dihilangkan. Hal ini tidak dapat diterima, karena model ini adalah Gravity Model. Dalam Gravity Model, variabel jarak merupakan model dasar sehingga tidak mungkin tidak diikutsertakan.

Uji Hausmann terhadap kedua model tersebut sesuai dengan Tabel 4.1 menunjukan bahwa hipotesa tidak dapat ditolak pada level kepercayaan 5 persen sehingga model yang lebih baik yaitu mempergunakan efek random. 
K. Dianta A. Sebayang: Dampak Integrasi Ekonomi ASEAN Terhadap Perdagangan Indonesia Pada Sektor Kendaraan Roda Empat

Tabel 4.1

\begin{tabular}{|l|l|l|}
\hline Model & x Hitung $(\mathrm{df}=7)$ & Kesimpulan \\
\hline SITC 3781 & 1.48 & Efek Random \\
\hline
\end{tabular}

\section{Hasil Regresi Kendaraan Roda Empat (SITC 3 781)}

Untuk memenuhi kriteria ekonometri model/persamaan harus memenuhi asumsi BLUE. Berdasarkan hal tersebut, model dalam penelitian ini diuji sesuai dengan prosedur ekonometri sebagai berikut:

\section{Uji Multikolineritas}

Uji multikolineritas dilakukan dengan melihat korelasi antar variabel. Materix korelasi antar variabel dapat dilihat dari Tabel 4.2 . Berdasarkan tabel tersebut, hasil pengujian menunjukkan bahwa tidak terdapat korelasi antar variable bebas (nilai korelasi antar variable tidak ada yang diatas 0,8). Tabel 4.2

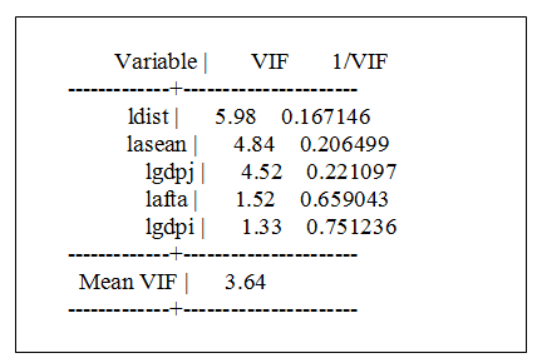

\section{Uji Heterokedasitas}

Ketika melakukan regresi pertama kali, didapat output seperti yang ada dalam Tabel 4.3.

Tabel 4.3

Outpur Regresi Pertama Model Kendaraan Roda Empat 781

\begin{tabular}{|c|c|c|c|c|}
\hline Source | & SS $\quad \mathrm{df}$ & If $\mathrm{MS}$ & & Number of obs $=128$ \\
\hline Model & 431.57964 & 586.31 & 59281 & Prob $>F=0.0000$ \\
\hline Residual & 358.717485 & $\begin{array}{lll}5 & 122 & 2.9\end{array}$ & 4030725 & R-squared $=0.5461$ \\
\hline -.--t+ & & & & Adj R-squared $=0.5275$ \\
\hline Total $\rfloor$ & 790.297125 & $127 \quad 6.22$ & 281201 & Root MSE $=1.7147$ \\
\hline ltotal & Coef. & Std. Err. & $\mathrm{t} \quad \mathrm{P}>|\mathrm{t}|$ & [95\% Conf. Interval] \\
\hline lgdpi | & 1.221045 & .5291898 & 2.310 .023 & $.1734608 \quad 2.268629$ \\
\hline lgdpj & .7759966 & 184381 & 4.210 .000 & $.410996 \quad 1.140997$ \\
\hline ldist & -2.1981 & .401527 & $-5.47 \quad 0.000$ & $\begin{array}{ll}-2.992962 & -1.403237\end{array}$ \\
\hline lafta & 3.261673 & .5501214 & $5.93 \quad 0.000$ & $2.172653 \quad 4.350693$ \\
\hline lasean & 3.858723 & 6670569 & $5.78 \quad 0.000$ & $2.538218 \quad 5.179229$ \\
\hline cons & 12.38496 & 3.816506 & 3.250 .002 & $4.829809 \quad 19.94012$ \\
\hline
\end{tabular}

Lalu dilakukan uji

heteroskedasitas (Breusch-Pagan /

Cook-Weisberg test for heteroscedasticity) terhadap regresi tersebut. Hasil pengujian tersebut menunjukkan bahwa terdapat 
masalah heteroskedasitas pada regresi ini. Oleh sebab itu, dilakukan treatment terhadap masalah ini. Menurut Gujarati, untuk menghilangkan masalah heteroskedasitas maka dapat dilakukan beberapa langkah. Langkah yang diambil penulis adalah membagi setiap variabel dengan standar deviasi dari varians errornya. Ouput regresi setelah dilakukan treatment adalah seperti Tabel 4.4.

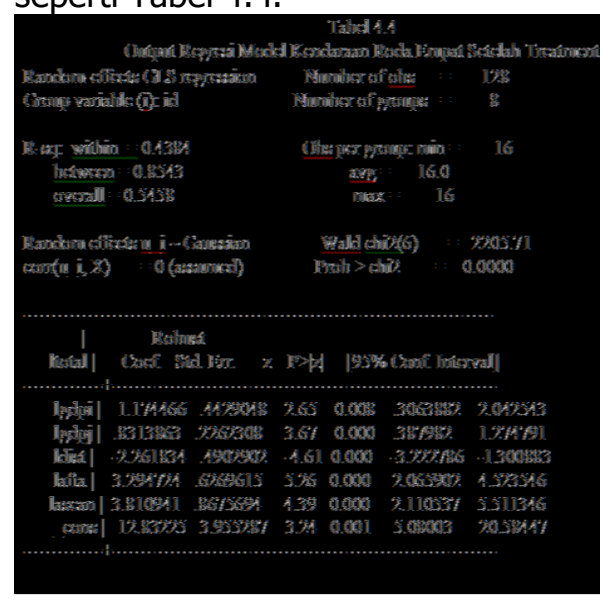

\section{Analisa Model Kendaraan Roda Empat (SITC 3 781)}

Hasil regresi pada Tabel 4.4 merupakan hasil regresi terbaik bagi model ini. Secara keseluruhan model ini mampu menjelaskan hubungan antara variabel dependen dengan variabel-variabel independen, dengan cukup baik yang dapat dilakukan dengan uji-F terhadap model. Dengan tingkat keyakinan $95 \%$, tolak $\mathrm{HO}$ jika a $(0,05)>F$ stat. Maka tolak $\mathrm{HO}$ karena a $(0,05)>F$ stat $(0,00)$. Ini berarti bahwa secara bersama-sama variabel-variabel independen yang ada dalam model mampu menjelaskan variasi pada perdagangan bilateral dengan baik. Nilai konstanta (constanta) dalam model ini signifikan ( $P$-value = 0,001). Ini berarti, jika nilai variabelvariabel independen adalah nol, maka perdagangan akan tetap ada nilainya, yaitu sebesar konstanta.

Variabel AFTA dengan tingkat keyakinan $95 \%$, tolak $\mathrm{H} 0$ jika a $(0,05)$ $>$ t stat. Maka tolak HO karena a $(0,05)>$ t stat $(0,677)$. Hal ini berarti bahwa variabel AFTA signifikan mempengaruhi perdagangan Indonesia dengan anggota ASEAN yang telah memberlakukan kesepakatan AFTA. Pengaruh dari variabel ini adalah positif, dengan koefisien 3.294724. Dengan kata lain setiap sejak diberlakukan AFTA, maka terjadi peningkatan perdagangan sebesar 3,3\%

Sedangankan Variabel ASEAN dengan tingkat keyakinan 95\%, tolak $\mathrm{HO}$ jika a $(0,05)>\mathrm{t}$ stat. Maka tolak H0 karena a $(0,05)>t$ stat $(0,677)$. Hal ini berarti bahwa variabel ASEAN signifikan mempengaruhi perdagangan Indonesia dengan anggota ASEAN. Pengaruh dari variabel ini adalah positif, dengan koefisien 3.810941. Dengan kata lain, perdagangan Indonesia dengan anggota ASEAN lebih besar 3,8\% dibandingkan dengan mitra dagang non-ASEAN.

\section{KESIMPULAN}

1. Berdasarkan hasil estimasi, model gravitasi mampu menjelaskan dampak AFTA terhadap perdagangan internasional Indonesia pada produk kendaraan roda empat. 
2. Variabel GDP Indonesia dengan GDP mitra dagang dan jarak signifikan menjelaskan arus perdagangan Indonesia dengan mitra dagang baik negara-negara ASEAN maupun non-ASEAN, baik pada produk kendaraan roda empat.

3. Variabel boneka dependen AFTA dalam model ini model signifikan mempengaruhi variabel independen.

4. Variabel boneka dependen ASEAN signifikan dalam model SITC 781, yaitu pada perdagangan kendaraan roda empat.

\section{Saran Kebijakan}

Saran kebijakan yang
ditawarkan oleh penulis bagi regulator-regulator di dalam organisasi ASEAN, adalah kebijakan yang berkaitan dengan peningkatan kerjasama ekonomi. Saran tersebut antara lain, adalah:

1. Untuk meningkatkan integrasi ekonomi ASEAN sektor otomotif harus dijadikan sebagai percontohan bagi sektor-sektor unggulan ASEAN lainnya.

2. Dengan adanya spesialisasi produk sparepart negaranegara ASEAN dapat berkonsentrasi pada peningkatkan mutu kualitas barang hasil produksinya sehingga akan meningkatkan keunggulan ekspor.

3. Negara-negara ASEAN harus membuat kesepakatan bersama yang mengatur pembuatan barang jadi yang dihasilkan dari komponen-komponen yang dibuat oleh masing-masing negara.

4. Negara-negara ASEAN merumuskan pengaturan spesialisasi produk unggulan dari masing-masing negara sesuai dengan kemampuan dan peluang masing-masing negara.

5. Pengambil kebijakan negaranegara anggota ASEAN dan sektor swasta, terutama perusahaan Multi National Company (MNC), harus meningkatakan koordinasi dan kerjasamanya antar negara ASEAN menjadi lebih efisien dan efektif.

\section{DAFTAR PUSTAKA}

Arifin, Syamsul, Rae, Dian, and Joseph, Charles. 2007, Kerjasama Perdagangan Internasional, PT Elex Media Komputino, Jakarta Cordenillo, Raul L., The Future of the ASEAN Free Trade Area and the Free Trade Areas between ASEAN and its Dialogue Partners. Investment and Enterprice Unit of the Bureau for Economic Intergration of the ASEAN Secretariat. Jakarta

Deardorff, Alan V. 1995, Determinants of Bilateral Trade: Does Gravity Work in a Neoclassical World?. National Bureau of Economic Research, Cambridge.

Hoa, Tran Van, 2003, New Asian Regionalism: Evidence on ASEAN+3 Free Trade Agreement From Extended Gravity Theory and New Modelling Approach. Economics Working Paper Series, University of Wollongong. 
Humphrey, John, 2003, The Global Automotive Industry Value Chain, UNINDO.Vienna

Ito, Keiko, 2004, Intra-Industry Trade in the ASEAN Region: The Case of the Automotive Industry, Working Paper Seriers Vol 2004-23 ICSEAD

Krugman, Paul $\mathrm{R}$ and Maurice Obstfeld,(2000), International Economics, Fifth Edition, Pearson Education International.

Mituiassu, 2003, The Impact of Regional Integration Schemes on Automobile and Autoparts Trade. Forum of International Development Studies No.23.

Paas, Tiuu, (2000) Gravity Approach for Modeling Trade Flows Between Estonia and The Main Trading Partners, No.4. Tartu: University of Tartu.

Rudy, May 2007, Ekonomi Politik Internasional, Nuansa, Bandung

Salvatore, Dominick, 2004, International Economics, Wiley. New Jersey

Sandro Leidi, Roger Stern, Brigid McDermott and Savitri Abeyasekera, 2006, Stata 9 for Surveys manual. United Kingdoms

Sohn, Chan-Hyun, Does the Gravity Model Fit Korea's Trade Patterns?, Korea Institute for International Economic Policy (KIEP), South Korea.

Stiglitz, Joseph, 2006, Making Globalization Work, W.W.Norton\&Company. New York Tarigan, Robinson, 2006, Ekonomi Regional, Bumi Aksara, Jakarta

Bahan/Sumber Lain

....1992, Agreement on the Common Effective Preferential Tariff
Scheme for the ASEAN Free Trade Area

....Article XXIV GATT/WTO (yang memberikan rambu-rambu pembentukan wilayah perdagangan bebas (custom union) dan FTA).

.....1998, ASEAN Framework Agreement on the Facilitation of Goods in Transit.

.....2006, ASEAN Statistical Yearbook 2005.

....1992, Framework Agreement on Enhancing ASEAN Economic Cooperation.

.....2006, PERATURAN PRESIDEN

REPUBLIK INDONESIA NOMOR

16 TAHUN 2006

WITS-COMTRADE

www.aseansec.org

www.imf.org

www.indo.com/distance. 